Jurnal SOSIO DIALEKTIKA 6 (2) (2021)

p-ISSN: 2540.8941 e-ISSN: 2623.2944

e-mail; sosiodialektika@unwahas.ac.id

doi; http://dx.doi.org/10.31942/sd.v6i2.5677
Evaluasi Komunikasi: Studi Kasus

Pelaksanaan Program

Pemberdayaan Masyarakat Penggiat Anti Narkoba Oleh BNN

\title{
Evaluasi Komunikasi: Studi Kasus Pelaksanaan Program Pemberdayaan Masyarakat Penggiat Anti Narkoba Oleh BNN Jakarta Timur
}

\author{
Sylvia Roennfeld ${ }^{1}$, Sophia Bernadette ${ }^{2}$ \\ Prodi Hubungan Masyarakat, Fakultas Komunikasi \\ Institut Komunikasi dan Bisnis LSPR Jakarta, Indonesia \\ sylvia.ar@1spr.edu ${ }^{1}, \underline{\text { sophia.b@1spr.edu }}^{2}$
}

\begin{abstract}
Abstrak
The problem of drug abuse and trafficking is increasingly becoming a problem for every country worldwide, including Indonesia. DKI Jakarta, as the state capital, ranks third nationally in narcotics abuse, with a trial use prevalence rate reaching $4.9 \%$. In this study, researchers will focus on evaluating communication programs carried out through technical guidance carried out by BNN for anti-drug activists in the educational environment. We utilized the four stages of program planning by Cutlip, Center and Broom, to get a picture of the situation, program planning and form of communication, which will elaborate further on aspects of communication evaluation based on the Yardstick evaluation model.
\end{abstract}

Keywords: BNN, Community Empowerment, Drugs, Public Relations, Yardstick Evaluation

\section{A. PENDAHULUAN}

Permasalahan penyalahgunaan dan peredaran narkoba yang semakin mewabah menjadi persoalan bagi setiap negara di seluruh dunia termasuk Indonesia. Berdasarkan dari data hasil Survei BNN-UI (2011) tentang Survei bahwa angka prevalensi penyalahguna Narkoba di Indonesia telah mencapai $2,2 \%$ atau sekitar 3,8 juta orang dari total populasi penduduk (berusia 10-60 tahun) (BNN, 2019).

Kerja sama pemerintah dan masyarakat dalam menjawab tantangan ini dapat dipenuhi dengan sukses melalui sinergi yang terukur dan terencana. Peningkatan partisipasi masyarakat adalah implementasi yang prioritas dan 
Jurnal SOSIO DIALEKTIKA 6 (2) (2021)

p-ISSN: 2540.8941 e-ISSN: 2623.2944

e-mail; sosiodialektika@unwahas.ac.id

doi; http://dx.doi.org/10.31942/sd.v6i2.5677
Evaluasi Komunikasi: Studi Kasus

Pelaksanaan Program

Pemberdayaan Masyarakat

Penggiat Anti Narkoba Oleh BNN

Jakarta Timur

penting untuk dikedepankan. Sementara pemeliharaan program pencegahan dan pengawasan diarahkan sebagai rencana aksi bersama melalui pendekatan komunitas dan kearifan lokal yang dapat digunakan pula untuk mencegah dan mengendalikan penyalahgunaan dan peredaran gelap narkoba.

Berdasarkan hasil survey BNN dan UI tentang Penyalahgunaan Narkoba pada Kalangan Pelajar dan Mahasiswa (2009), angka prevalensi Penyalahgunaan Narkoba Di lingkungan pendidikan (SLTP, SMU dan PT) dalam setahun terakhir sebesar 4,7).Dari fakta dan data di atas, terlihat bahwa 21,5\% kejahatan Narkoba dilakukan oleh pelaku yang seharus-nya masih berusia belajar sekolah dan kuliah (12-24 tahun) (https://bnn.go.id/konten/unggahan/2019/10/blue-print-dayamas-BNN.pdf).

DKI Jakarta sebagai ibukota negara yang menempati urutan ketiga nasional dalam penyalahgunaan narkotika dengan angka prevalensi coba pakai mencapai 4,9\%. Dilansir dari rilis berita di laman bnn.go.id, Deputi Pemberdayaan Masyarakat dalam sambutannya yang diwakili oleh Kasubdit Lingkungan Pendidikan, Wilda $\mathrm{Dj}$, M.Si., menyampaikan pentingnya penanganan secara intensif dalam dunia pendidikan karena anak-anak, remaja, kalangan pelajar, dan mahasiswa merupakan target pasar dari para pengedar narkotika (bnn.go.id, n.d).

Menjawab tantangan tersebut, BNN melalui program Pemberdayaan Masyarakat berusaha untuk memberikan panduan tentang cara untuk memobilisasi masyarakat agar berpartisipasi aktif dalam perencanaan, pelaksanaan, dan evaluasi program-program pemberdayaan masyarakat guna terwujudnya lingkungan bebas narkoba.Tugas pokok bidang pemberdayaan masyarakat adalah Melaksanakan program Pencegahan dan Pemberantasan Penyalahgunaan dan Peredaran Gelap Narkotika (P4GN) di bidang pemberdayaan masyarakat, baik Pemberdayaan Peran Serta Masyarakat maupun Pemberdayaan Alternatif (bnn.go.id, n.d).

Melihat pentingnya tujuan yang ingin dicapai pada program pemberdayaan masyarakat untuk pencegahan dan pemberantasan penyalahgunaan dan peredaran gelap narkotika, maka perlu adanya strategi yang jelas dan terukur, dimulai dari perencanaan, pelaksanaan maupun 
Jurnal SOSIO DIALEKTIKA 6 (2) (2021)

p-ISSN: 2540.8941 e-ISSN: 2623.2944

e-mail; sosiodialektika@unwahas.ac.id

doi; http://dx.doi.org/10.31942/sd.v6i2.5677
Evaluasi Komunikasi: Studi Kasus

Pelaksanaan Program

Pemberdayaan Masyarakat

Penggiat Anti Narkoba Oleh BNN

Jakarta Timur

evaluasi programnya yang mana hal tersebut merupakan essensi dari program kerja Public Relations. Secara definisi Public Relations merupakan keseluruhan upaya yang dilakukan secara terencana dan berkesinambungan dalam rangka menciptakan dan memelihara niat baik (good-will) dan saling pengertian antara suatu organisasi dengan segenap khalayak (British Institute of Public Relations). Dalam upayanya untuk mengeksekusi tujuan organisasi untuk menanamkan pengertian yang baik kepada khalayak, Public Relations melakukan perencanaan yang berkesinambungan dan dibuat berdasarkan riset yang komprehensif. Riset digunakan untuk mendapatkan gambaran situasi yang dihadapi, mengidentifikasi target public, penentuan strategi komunikasi, penentuan program kerja, pemilihan media sampai dengan evaluasi program komunikasi yang sudah dilakukan.

Lebih lanjut Cutlip menjelaskan proses management perencanaan pada Public Relations dibagi dalam 4 tahapan yaitu Analisa terhadap situasi dan permasalahan (Defining the problem), Perencanaan dan program (planning and programing), Aksi dan komunikasi (Taking action and Communicating) dan Evaluasi (Evaluation) (2012: 319). Pada tahapan pertama, ditujukan untuk mencari fakta fakta agar dapat mengidentifikasi masalah atau situasi yang sedang dihadapi, Setelah mendapatkan gambaran situasi permasalahanya mulai ditentukan perencanaan dan program, kemudian dilanjutkan dengan aksi dan pemilihan komunikasi yang pada akhirnya dilihat pencapaiannya melalui evaluasi program.

Tahapan evaluasi merupakan bagian yang cukup penting dalam melihat keberhasilan program yang diukur berdasarkan tujuan yang ingin dicapai Selain itu evaluasi juga di gunakan sebagai acuan dalam menentukan strategi komunikasi yang berkelanjutan. Ike Devi Sulistyaningtias dalam "Riset sebagai Ujung Tombak Keberhasilan Program Public Relations" (Jurnal Ilmu Komunikasi, Vol.7 No.2, 2010:183) menyatakan bahwa Walter Lindenmann, seorang praktisi PR dari Amerika mengemukakan metode evaluasi program komunikasi "Yardstick" untuk melakukan pendekatan riset dan evaluasi berdasarkan tiga level. Dengan menggunakan level berjenjang maka tingkat ketelitian lebih tinggi dibandingkan proses kronologis dari komunikasi itu sendiri yang dimulai 
Jurnal SOSIO DIALEKTIKA 6 (2) (2021)

p-ISSN: 2540.8941 e-ISSN: 2623.2944

e-mail; sosiodialektika@unwahas.ac.id

doi; http://dx.doi.org/10.31942/sd.v6i2.5677
Evaluasi Komunikasi: Studi Kasus

Pelaksanaan Program

Pemberdayaan Masyarakat

Penggiat Anti Narkoba Oleh BNN

Jakarta Timur

dari perencanaan sampai dengan implementasian hingga pencapaian objective.

Level 1, yaitu evaluasi output seperti pengaruh dari pemilihan media dengan melihat jumlah total audiens yang dapat dijangkau. Artinya apakah penempatan pesan pada media tertentu sudah cukup menjangkau target audiens. Level 2, yaitu evaluasi lanjutan dan memperhitungkan pemahaman kesadaran dan penerimaan. Ketika pesan sudah ditempatkan pada media tertentu, perlu dievaluasi apakah pesan yang sampai pada audiens sesuai dengan pesan yang diharapkan sampai pada audiens. Level 3 merupakan level advance, fokus pada pengukuran perubahan opini, perubahan sikap sampai pada perubahan tingkah laku.

Pada penelitian ini, peneliti akan memfokuskan pada evaluasi program komunikasi yang sudah dilakukan melalui bimbingan teknis yang di lakukan oleh BNN terhadap para penggiat anti Narkoba di lingkungan pendidikan. Dengan mengunakan acuan 4 tahapan perencanaan program dari Cutlip, Center dan Broom, untuk mendapatkan gambaran situasi, perencanaan program dan bentuk komunikasinya, yang kemudian akan di elaborasi lebih dalam pada aspek evaluasi komunikasinya berdasarkan model evaluasi Yardstick.

Berdasarkan definisi di atas, konsep Public Relations sejalan dengan apa yang dilakukan Badan Narkotika Nasional (BNN) sebagai sebuah institusi independen Pemerintah yang memiliki tujuan untuk membangun hubungan yang baik anatara institusi dengan publiknya. Dengan demikian, sejumlah kebijakan dan pesan dari institusi diharapkan bisa diterima dengan baik oleh masyarakat. Begitu juga sebaliknya, aspirasi dari masyarakat dapat tersampaikan kepada pihak institusi.

Ramlan secara spesifik mendefinisikan kampanye sosial sebagai sebuah proses untuk mengkomunikasikan pesan-pesan yang berisi tentang masalah-masalah sosial kemasyarakatan dan juga bersifat non-komersil. Tujuan umum dari kampanye sosial sendiri adalah untuk menumbuhkan kesadaran masyarakat akan gejala sosial yang sedang terjadi (Ramlan, 2006:19). Karena kampanye sosial dikatakan sebuah proses dan serangkaian 
Jurnal SOSIO DIALEKTIKA 6 (2) (2021)

p-ISSN: 2540.8941 e-ISSN: 2623.2944

e-mail; sosiodialektika@unwahas.ac.id

doi; http://dx.doi.org/10.31942/sd.v6i2.5677
Evaluasi Komunikasi: Studi Kasus

Pelaksanaan Program

Pemberdayaan Masyarakat

Penggiat Anti Narkoba Oleh BNN

Jakarta Timur

tindakan komunikasi terencana maka diperlukan strategi yang tepat untuk dapat menyampaikan pesan secara efektif terhadap target audiens.

Penelitian ini turut memperhatikan bagaimana efektifitas sebuah program pemberdayaan masyarakat dalam kampanye sosial Anti Narkoba dilakukan oleh BNN sebagai institusi. Selanjutnya yang menjadi tahapan adalah evaluasi yang dilaksanakan untuk menentukan atau memperlihatkan nilai suatu program termasuk pengelolaan maupun hasil atau dampak pelaksanaannya. Melalui evaluasi, Public Relations akan mengetahui faktorfaktor yang menjadi kegagalan atau keberhasilan suatu program sehingga dapat ditentukan langkah-langkah selanjutnya yang seharusnya dilakukan.

Menurut Gregory (2004:138) evaluasi adalah suatu proses yang berkelanjutan dan jika hal ini dilaksanakan dengan benar dapat memudahkan untuk mengendalikan dan mengontrol setiap kegiatan Public Relations. Evaluasi harus dilakukan secara berkala dimana hal ini berkaitan erat dengan hal - hal sebagai berikut: (a) Evaluasi dapat memfokuskan usaha; (b) Evaluasi dapat menunjukan keefektifan; (c) Evaluasi dapat memastikan efisiensi biaya; (d) Evaluasi dapat mendukung manajemen untuk menjadi lebih baik; (e) Evaluasi dapat memfasilitasi pertanggungjawaban. Pada penelitian ini, tahap evaluasi menjadi fokus penelitian untuk mengetahui bagaimana efektifitas program pemberdayaan masyarakat yang dilakukan oleh Badan Narkotika Nasional (BNN) dalam mensosialisasikan Kampanye Anti Narkoba di Jakarta Timur.

Model evaluasi Yardstick ini dikemukakan oleh Walter Lindemann sebagai pendekatan baru dalam riset dan evaluasi PR yang didasarkan pada pada tiga level kedalaman dan kesesuaian program Public Relations (Public Relations Review, Vol.16, No. 2, 1990: 3-24). Dalam evaluasi dibagi menjadi tiga bagian. Bagian pertama yaitu level output adalah evaluasi mengenai pencapaian target audience atau sasaran program serta media placement yang terjadi baik sebelum terlaksananya program, saat terlaksana, maupun pasca terlaksananya program.

Bagian kedua yaitu level intermediate menjelaskan mengenai bagaimana mengukur pemahaman, retensi, kesadaran, dan penerimaan target audiens dengan program yang diterima. Lalu apakah mereka terus 
Jurnal SOSIO DIALEKTIKA 6 (2) (2021)

p-ISSN: 2540.8941 e-ISSN: 2623.2944

e-mail; sosiodialektika@unwahas.ac.id

doi; http://dx.doi.org/10.31942/sd.v6i2.5677
Evaluasi Komunikasi: Studi Kasus

Pelaksanaan Program

Pemberdayaan Masyarakat

Penggiat Anti Narkoba Oleh BNN

Jakarta Timur

mengingat dan memahami mengapa program ini diberlakukan, apa makna dan tujuan dari pelaksanaan program sehingga target audiens dapat melaksanakan program ini karena adanya kesadaran untuk meningkatkan diri mereka sendiri menjadi lebih baik.

Bagian ketiga adalah advanced level, di mana pada level ini sudah tercermin tujuan jangka panjang dari hasil audit dan implementasi program. Dalam level ini diharapkan sudah tumbuh rasa terbiasa dari target audiens untuk melaksanakan program ini dengan baik dan tanpa paksaan atau menjadi kebiasaan sehari-hari yang merubah behavior dan attitude mereka. Lalu mereka juga sudah bisa memberikan opini mereka baik terhadap perubahan yang ada, sampai masukan kepada perusahaan seperti pujian kepuasan, dan menjadi representative perusahaan yang baik dihadapan seluruh publik.

Evaluasi Model Yardstick digunakan sebagai acuan dalam penelitian ini untuk memberikan hasil yang mendalam mengenai keberhasilan dan keefektifitasan program pemberdayaan masyarakat yang dilakukan oleh BNN dalam mengkomunikasikan Kampanye Anti Narkoba di Jakarta Timur. Pemberdayaan Masyarakat menurut Soetrisno dalam Jacob (2000: 185), pemberdayaan masyarakat atau empowerment adalah merubah kondisi program pembangunan yang sudah ada dengan cara memberi kesempatan pada kelompok orang miskin untuk merencanakan dan kemudian melaksanakan program pembangunan yang telah dipilihnya, serta memberikan kesempatan pada kelompok orang miskin untuk mengelola dana pembangunan dengan baik yang berasal dari pemerintah maupun pihak lain.

Sedangkan Kartasasmita (1995), mengemukakan bahwa pemberdayaan masyarakat adalah upaya untuk meningkatkan harkat dan martabat lapisan masyarakat untuk melepaskan diri dari perangkap kemiskinan dan keterbelakangan. Penelitian ini turut melihat bagaimana sebuah program pemberdayaan masyarakat yang dilakukan oleh BNN untuk mensosialisasikan tentang Kampanye Anti Narkoba di wilayah Jakarta Timur. 
Jurnal SOSIO DIALEKTIKA 6 (2) (2021)

p-ISSN: 2540.8941 e-ISSN: 2623.2944

e-mail; sosiodialektika@unwahas.ac.id

doi; http://dx.doi.org/10.31942/sd.v6i2.5677
Evaluasi Komunikasi: Studi Kasus

Pelaksanaan Program

Pemberdayaan Masyarakat

Penggiat Anti Narkoba Oleh BNN

Jakarta Timur

\section{B. METODE PENELITIAN}

Penelitian ini menggunakan penelitian yang bersifat kualitatif deskriptif. Penelitian kualitatif deskriptif adalah berupa penelitian dengan metode atau pendekatan studi kasus, yang memusatkan diri secara insentif pada suatu obyek tertentu, dan mempelajarinya sebagai suatu kasus. Data studi kasus dapat diperoleh dari semua pihak yang bersangkutan, dengan demikian dalam studi ini dikumpulkan dari berbagai sumber (Nawawi, 2003:1).

Fenomena yang menjadi kasus dalam penelitian ini adalah strategi komunikasi program pemberdayaan masyarakat penggiat anti narkoba oleh BNN di wilayah Jakarta Timur. Penelitian ini bertujuan untuk melihat evaluasi komunikasi atas program yang dilakukan oleh BNN tersebut.

Metode pengumpulan data menggunakan penelitian kepustakaan yang diperoleh melalui media cetak seperti buku, jurnal, laporan dari berbagai sumber juga yang berasal dari media elektronik seperti internet, sebagai data sekunder. Selain itu penulis menggunakan data primer yang diperoleh melalui wawancara bersama dengan pihak yang kompeten untuk menjawab persoalan dalam penelitian ini.

Data yang terkumpul akan dianalisis menggunakan kerangka teoritis yang telah ditentukan untuk dapat menjawab pertanyaan penelitian.

\section{HASIL DAN PEMBAHASAN}

\section{C.1. Gambaran Umum dan Analisis Situasi}

Untuk menghadapi ancaman dari aktifitas peredaran gelap narkoba yang semakin meningkat, pemerintah Indonesia memiliki komitmen tinggi untuk dapat memberantas penyalahgunaan narkoba. Komitmen tersebut juga terwujud dengan didirikannya Badan Narkotika Nasional (BNN). Badan Narkotika Nasional (BNN). merupakan lembaga negara bersifat non-kementerian yang memiliki tugas pokok melaksanakan program Pencegahan dan Pemberantasan Penyalahgunaan dan Peredaran Gelap Narkoba (P4GN) yang tertuang pada Peraturan Presiden Nomor 23 Tahun 2010. 
Jurnal SOSIO DIALEKTIKA 6 (2) (2021)

p-ISSN: 2540.8941 e-ISSN: 2623.2944

e-mail; sosiodialektika@unwahas.ac.id

doi; http://dx.doi.org/10.31942/sd.v6i2.5677
Evaluasi Komunikasi: Studi Kasus

Pelaksanaan Program

Pemberdayaan Masyarakat

Penggiat Anti Narkoba Oleh BNN

Jakarta Timur

BNN memiliki berbagai macam program untuk mewujudkan Indonesia bebas Narkoba, salah satunya adalah Program Pemberdayaan Masyarakat. Secara teoretis, program pemberdayaan dapat dipahami sebagai upaya untuk mencegah peningkatan angka peredaran gelap narkoba melalui upaya secara luas membantu masyarakat untuk dapat secara mandiri memperoleh daya dan menentukan tindakan yang dapat mengurangi efek hambatan pribadi dan sosial dalam melakukan tindakan dalam isu-isu tertentu, dalam kasus ini adalah penyalahgunaan narkoba (Nopitasari \& Rostyaningsih, 2017).

Dalam kaitan ini, Jakarta merupakan wilayah dengan angka penyalahgunaan narkoba tertinggi peringkat ke II dan juga menjadi wilayah peredaran gelap narkoba terbesar di negara ini. Salah satu yang menjadi pusat peredaran gelap narkoba terbesar di Jakarta, adalah Kampung Pertanian atau yang sering disebut sebagai Kebon Singkong. Kampung Pertanian terletak di Kelurahan Klender, Kecamatan Duren Sawit, Jakarta Timur. Di wilayah ini, peredaran gelap narkoba menjadi bisnis andalan para warga setempat untuk membiayai kehidupan mereka (Nopitasari \& Rostyaningsih, 2017). Oleh karena itu, BNN memberikan perhatian yang tinggi terhadap wilayah ini, sesuai dengan hasil wawancara dengan narasumber sebagai berikut:

Di dasarkan pada hal tersebut maka untuk daerah kota

Jakarta Timur kita mengadakan berbagai kegiatan yang sifatnya berkesinambungan, pada awalnya kita mengadakan kegiatan untuk pembekalan dan pelatihan kepada kelompok binaan yang kemudian kita lengkapi dan tindak lanjuti dengan kegiatan pelatihan lifeskill. (Siagian,

Wawancara Pribadi, 2021).

Institusi pendidikan menjadi target program pemberdayaan masyarakat untuk dapat bersama-sama memberantas penyalahgunaan narkotika. Kerja sama dan partisipasi dengan Institusi pendidikan menjadikan hal yang penting dalam upaya pencegahan dan 
Jurnal SOSIO DIALEKTIKA 6 (2) (2021)

p-ISSN: 2540.8941 e-ISSN: 2623.2944

e-mail; sosiodialektika@unwahas.ac.id

doi; http://dx.doi.org/10.31942/sd.v6i2.5677
Evaluasi Komunikasi: Studi Kasus

Pelaksanaan Program

Pemberdayaan Masyarakat

Penggiat Anti Narkoba Oleh BNN

Jakarta Timur

penyebaran Narkoba. Secara periodik BNN berusaha melakukan pembinaan kepada kader penggiat anti Narkoba di lingkungan pendidikan. Pembekalan pengetahuan dan kemampuan untuk melakukan sosialisasi menjadi sangat penting untuk menunjang keberhasilan program pemberdayaan masyarakat ini.

Oleh karena itulah, analisis di dalam tulisan ini ingin melakukan kajian mendalam terhadap implementasi program pemberdayaan masyarakat penggian anti-narkoba yang digagas oleh BNN tersebut secara akademis.

\section{C.2. Perencanaan dan Program Pemberdayaan Masyarakat oleh BNN}

Hingga saat ini, BNN telah memiliki berbagai macam programprogram unggulan dalam rangka mencegah penyebaran penyalahgunaan narkoba. BNN telah melakukan beberapa program unggulan secara massif bersama dengan seluruh komponen bangsa, mulai dari pemerintah pusat, pemerintah daerah, tokoh masyarakat, tokoh agama, tokoh pemuda serta para orangtua untuk mencegah penyalahgunaan dan peredaran narkotika. Beberapa program unggulan dari bidang pencegahan yang telah dilaksanakan selama tahun 2020, yaitu: (1) Rumah Edukasi Anti-Narkoba (REAN.ID) yang dapat diakses pada portal https://rean.bnn.go.id melalui portal ini, BNN menggelar lomba video kreatif dengan mengangkat kearifan budaya lokal dan dihubungkan dengan \#hidup100persen sebagai upaya pencegahan penyalahgunaan narkoba kepada masyarakat; (2) Aplikasi Sistem Pelaporan Relawan Anti-Narkoba (Siparel) yang memudahkan relawan dalam melakukan sosialisasi dan melaporkan kegiatannya; (3) Social Media Center (SMC) untuk melakukan pemantauan dan pengukuran terhadap aktivitas postingan media sosial terkait P4GN; (4) CNS podcast yang mengudara bersama berbagai narasumber yang kompeten dengan durasi 30 menit dengan bentuk dialog dua arah dalam kanal YouTube; (5) Kampanye dengan tema \#hidup100persen yang diharapkan menjadi sebuah gerakan massal, terutama bagi para 
Jurnal SOSIO DIALEKTIKA 6 (2) (2021)

p-ISSN: 2540.8941 e-ISSN: 2623.2944

e-mail; sosiodialektika@unwahas.ac.id

doi; http://dx.doi.org/10.31942/sd.v6i2.5677
Evaluasi Komunikasi: Studi Kasus

Pelaksanaan Program

Pemberdayaan Masyarakat

Penggiat Anti Narkoba Oleh BNN

Jakarta Timur

pekerja media dan lingkungan kementrian atau lembaga untuk bersama-sama digelorakan hastag atau tagar ini di berbagai lapisan masyarakat; (6) Desa Bersinar (Bersih Narkoba) bekerja sama dengan pemerintah setempat, masyarakat, dan swasta membentuk strategi dengan membuat regulasi, kegiatan P4GN, relawan antinarkoba, dan agen pemulihan; (7) Membentuk relawan antinarkoba yang sampai dengan saat ini BNN telah memiliki 6.290 orang relawan yang tersebar di seluruh Indonesia; (8) Intervensi ketahanan keluarga berbasis sumber daya desa sebagai prioritas nasional; (9) Strategi menggunakan media konvergensi seperti kampanye media sosial dan situs web atau berbagai platform untuk berkomunikasi secara langsung dan interaktif kepada publik (Gatra.com, 2020). Seluruh program-program tersebut dilaksanakan secara nasional dengan strategi koordinasi yang melibatkan pemerintah daerah setempat, selain itu program-program tersebut juga didukung oleh berbagai lembaga anti-narkoba internasional. Seperti yang dinyatakan oleh narasumber penelitian ini salah seorang pejabat di BNN,

Memang ada beberapa program unggulan yang telah dibuat oleh BNN untuk mengatasi dan mengantisipasi peredaran narkoba dan penggunaannya. Saya bertugas untuk menyusun dan melaksanakan renstra dan renker tahunan di bidang pencegahan dan pemberantasan penyalahgunaan dan peredaran gelap narkotika, psikotropika, prekursor, dan bahan adiktif lainnya kecuali bahan adiktif untuk tembakau dan alkohol yang selanjutnya disebut P4GN dalam wilayah kota Jakarta Timur. Saya juga sebagai pelaksana kebijakan teknis di bidang pencegahan, pemberdayaan masyarakat, rehabilitasi, dan pemberantasan dalam wilayah kota yang akan di supervise oleh BNNP. Kemudian saya juga bertugas untuk melaksanakan layanan hukum dan kerja sama dalam wilayah kota, koordinasi dan kerja sama P4GN dengan instansi pemerintah terkait dan komponen 
Jurnal SOSIO DIALEKTIKA 6 (2) (2021)

p-ISSN: 2540.8941 e-ISSN: 2623.2944

e-mail; sosiodialektika@unwahas.ac.id

doi; http://dx.doi.org/10.31942/sd.v6i2.5677
Evaluasi Komunikasi: Studi Kasus

Pelaksanaan Program

Pemberdayaan Masyarakat

Penggiat Anti Narkoba Oleh BNN

Jakarta Timur

masyarakat dalam wilayah kota Jakarta Timur; serta melaksanakan fungsi pelayanan administrasi, evaluasi dan pelaporan BNNKI (Widagdo, Wawancara Pribadi, 2021).

Program-program BNN juga dirancang untuk secara menukik berinteraksi langsung dengan masyarakat akar rumput dengan pendekatan membentuk relawan penggait anti-narkoba. BNN menyelenggarakan Pembentukan Penggiat Anti Narkoba di seluruh Indonesia, baik yang berada di lingkungan pemerintahan, lingkungan pendidikan, dan tempat kerja. Di tahun 2019 ini BNN telah berhasil membentuk Penggiat Anti Narkoba di seluruh Indonesia sebanyak 29.485 orang. Lalu BNN juga bekerjasama dengan seluruh stakeholders di tahun 2019 ini telah melakukan tes urine secara masif di seluruh Indonesia sebanyak 5.399 kegiatan (Siagian, Wawancara Pribadi, 2021).

Program Intervensi Berbasis Masyarakat (IBM) merupakan pengembangan dari Desa Bersinar, sehingga program IBM juga bersinergi dengan beberapa Kementerian seperti Kementerian Dalam Negeri, Kementerian Desa, Kementerian Sosial dan Kementerian Kesehatan serta pemerintahan lokal (kecamatan, kelurahan dan desa). Bahkan untuk memastikan pencegahan penyalahgunaan narkoba sejak dini, program-program di atas juga dilaksanakan di institusi-intitusi pendidikan hingga tataran Pendidikan Usia Dini di Jakarta Timur. Seperti keterangan dari narasumber penelitian ini,

Jadi Mbak kita punya program, namanya SINAR, yaitu BERSIH NARKOBA. Yang dulu kita buat penggiat ya, penggiat yaitu agent of change di lingkungannya. Salah satunya yaitu di pendidikan, ya pendidikan itu adanya di kampus, di pesantren dan juga sekolah-sekolah. Masuk sekolah-sekolah di tingkat SD, SMP, SMA. Tapi kalau di bidang pencegahan kita bahkan sudah masuk sampai ke 
Jurnal SOSIO DIALEKTIKA 6 (2) (2021)

p-ISSN: 2540.8941 e-ISSN: 2623.2944

e-mail; sosiodialektika@unwahas.ac.id

doi; http://dx.doi.org/10.31942/sd.v6i2.5677
Evaluasi Komunikasi: Studi Kasus

Pelaksanaan Program

Pemberdayaan Masyarakat

Penggiat Anti Narkoba Oleh BNN

Jakarta Timur

tingkat sekolah TK. Kita punya metode masuk sampai ke

sekolah TK (Widagdo, Wawancara Pribadi, 2021).

Upaya pencegahan penyalahgunaan narkotika sejak usia dini sangat penting dilaksanakan karena menurut data dari BNN, penyalahgunaan narkotika di kalangan remaja makin meningkat. Di mana ada peningkatan sebesar 24 hingga 28 persen remaja yang menggunakan narkotika. Salah satu kelompok masyarakat yang rawan terpapar penyalahgunaan narkoba adalah mereka yang berada pada rentang usia 15-35 tahun atau generasi milenial (PUSLIDATIN, 2019). Oleh karena itu, program-program BNN secara khusus juga ditargetkan untuk mengantisipasi ancaman hancurnya masa depan anak bangsa karena Narkoba di masa yang akan datang.

\section{C.3. Aksi dan Komunikasi Program Pemberdayaan Masyarakat BNN: Strategi Aksi, Strategi Komponen Komunikasi dan Implementasi Strategi Public Relations.}

Pada bagian ini, analisis tulisan ini akan melihat aksi dan komunikasi Program Pemberdayaan Masyarakat BNN. Public Relations harus melakukan mengambil tindakan dan komunikasi dengan memperhatikan tiga hal, yaitu: strategi aksi, strategi komponen komunikasi dan implementasi strategi Public Relations.

Dalam konteks strategi aksi, BNN memiliki strategi yang menyasar kombinasi antara pencegahan dan pemberdayaan lingkungan disatukan melalui mobilitas kekuatan masyarakat untuk mengantisipasi penyalahgunaan narkoba di dalam lingkungan. Upaya tersebut dilengkapi modul dan materi-materi edukatif yang lengkap seperti film ataupun video singkat. Seperti yang diungkapkan oleh narasumber penelitian ini,

Deputi Bidang Pencegahan yang memiliki kewenangan kesana. Kalau kita menggerakkan mobilitas kekuatan masyarakat. Tapi bidang pencegahan sudah memiliki metode nya, modulnya, medianya, semuanya sudah ada.

Dalam bentuk film, dalam bentuk peragaan, dsb. Hanya 
Jurnal SOSIO DIALEKTIKA 6 (2) (2021)

p-ISSN: 2540.8941 e-ISSN: 2623.2944

e-mail; sosiodialektika@unwahas.ac.id

doi; http://dx.doi.org/10.31942/sd.v6i2.5677
Evaluasi Komunikasi: Studi Kasus

Pelaksanaan Program

Pemberdayaan Masyarakat

Penggiat Anti Narkoba Oleh BNN

Jakarta Timur

karena ke depan ini kita sedang melakukan terobosan dimana bidang pencegahan dan pemberdayaan ini digabungkan, maka kita akan menyasar lingkungan BERSINAR. Jadi lingkungan yang BERSIH NARKOBA itu dimulai dengan pemahaman2 Narkoba dengan sangat detil, metode nya juga diubah dari tadinya hanya SEKEDAR berupa penyuluhan2, sekarang sudah lebih kepada simulasi, role model, praktek, dalam bentuk peran sandiwara begitu. (Widagdo, Wawancara Pribadi, 2021)

Pendekatan yang dilakukan oleh BNN ini dilaksanakan setelah melakukan studi banding yang mendalam terhadap upaya pencegahan penyebaran narkotika di masyarakat ke luar negeri. Salah satu benchmark dari BNN adalah keberhasilan Filipina mengimplementasikan metode pencegahan penyalahgunaan narkotika melalui pemberian efek rasa takut untuk orang menggunakan Narkoba. Hal ini diungkapkan oleh narasumber penelitian ini sebagai berikut,

Terus terang, hal itu kami pelajari juga dari yang dilakukan di Filipina yang sudah maju. Jadi Filipina itu membuat metode bagaimana membuat orang takut Narkoba, membuat hidup suasana yang menggambarkan bagaimana proses orang bertransaksi, kemudian seperti apa pemakai yang teler, peran orang tua juga turut diperagakan. Kebetulan saya dapat kesempatan mengikuti studi banding disana selama kira-kira 2 minggu. Jadi kita melihat langsung on the spot. (Widagdo, Wawancara Pribadi, 2021).

Berlandaskan pada pengetahuan dari belajar ke negara lain yang telah berhasil menerapkan program pencegahan penyalahgunaan Narkoba, BNN merumuskan berbagai program-program unggulan yang masing-masing program sasarannya berbeda. Menurut 
Jurnal SOSIO DIALEKTIKA 6 (2) (2021)

p-ISSN: 2540.8941 e-ISSN: 2623.2944

e-mail; sosiodialektika@unwahas.ac.id

doi; http://dx.doi.org/10.31942/sd.v6i2.5677
Evaluasi Komunikasi: Studi Kasus

Pelaksanaan Program

Pemberdayaan Masyarakat

Penggiat Anti Narkoba Oleh BNN

Jakarta Timur

pemaparan dari narasumber penelitian ini, BNN memiliki program yang sasarannya adalah untuk pencegahan penggunaan dan penyebaran narkotika, ada yang untuk pemberdayaan masyarakat, dan ada juga untuk program rehabilitasi. Lalu ada lagi program yang memang untuk menyasar kepada hukum dan Kerjasama. Jadi semuanya harus bersinergi satu dengan yang lain. Sedangkan untuk program pemberdayaan masyarakat, yang bisa dikatakan menjadi program unggulan adalah kegiatan Penggiat Anti Narkoba di seluruh Indonesia, baik yang berada di lingkungan pemerintahan, lingkungan pendidikan, dan tempat kerja. Lalu BNN juga membuat Kegiatan Pemberdayaan Alternatif melalui pengembangan wirausaha bagi masyarakat Kawasan rawan dan rentan narkoba (Widagdo, Wawancara Pribadi, 2021). Program pemberdayaan masyarakat ini mulai diberlakukan sejak tahun 2010 melalui Peraturan Presiden Republik Indonesia Nomor 23 Tahun 2010 tentang Badan Narkotika Nasional.

Program ini sangat penting untuk membangun interaksi dan komunikasi BNN dengan seluruh masyarakat yang rentan terhadap ancaman penyalahgunaan narkoba, oleh karena itu maka target utama pada kegiatan ini adalah Para Pendidik yang menjadi penggiat anti Narkoba di Lingkungan/Institusinya masing masing, dan diharapkan mereka akan menjadi motor dalam memberikan sosialisasi mengenai Bahaya penyebaran Narkotika di lingkungan pendidikan di wilayah kota Jakarta Timur. Menurut hasil wawancara, ada 3 fase yang dilakukan untuk melaksanakan kegiatan ini, Dimulai dari fase persiapan, pelaksanaan dan terakhir adalah evaluasi atau follow up kegiatan. Persiapan yang di lakukan kurang lebih 1 bulan sebelum dimulainya kegiatan, lalu pelaksanaan dan evaluasi yang dilakukan setelah kegiatan kurang lebih sampai 1 bulan, karena salah satu bentuk evaluasinya adalah dengan mendatangi para peserta binaan dan melihat langsung implementasi dari kegiatannya. Kemudian dilanjutkan dengan fase pelaporan yaitu pembuatan laporan kegiatan sebagai bentuk pertanggung jawaban secara tertulis. 
Jurnal SOSIO DIALEKTIKA 6 (2) (2021)

p-ISSN: 2540.8941 e-ISSN: 2623.2944

e-mail; sosiodialektika@unwahas.ac.id

doi; http://dx.doi.org/10.31942/sd.v6i2.5677
Evaluasi Komunikasi: Studi Kasus

Pelaksanaan Program

Pemberdayaan Masyarakat

Penggiat Anti Narkoba Oleh BNN

Jakarta Timur

Medium komunikasi yang dilakukan untuk menyampaikan pesan utama adalah melalui para narasumber, lalu BNN juga memberikan brochure dan flyer serta buku panduan yang berisi informasi mengenai apa itu narkoba dan jenis jenisnya serta pengetahuan lainnya yang bertujuan untuk pencegahan dan penyebaran Narkoba di lingkungan pendidikan. Pertimbangan utama dalam memilih medium medium tersebut diawali mulai dari pemilihan narasumber yang berkompeten di bidangnya masing masing, lalu untuk brochure dan flyer karena medium tersebut bisa menjadi pengingat bagi para peserta didik mengenai materi yang sudah di sampaikan.

\section{C.4. Evaluasi Program Pemberdayaan Masyarakat oleh BNN di Jakarta Timur}

Menurut Gregory (2004: 138) evaluasi adalah suatu proses yang berkelanjutan dan jika hal ini dilaksanakan dengan benar dapat memudahkan untuk mengendalikan dan mengontrol setiap kegiatan Public Relations. Evaluasi harus dilakukan secara berkala dimana hal ini berkaitan erat dengan upaya untuk perbaikan terus-menerus. Dalam kaitan ini, penelitian yang dilakukan melakukan evaluasi terhadap program pemberdayaan masyarakat penggiat anti-narkoba di Jakarta Timur menggunakan Model evaluasi Yardstick ini dikemukakan oleh DR. Walter Lindemann sebagai pendekatan baru dalam riset dan evaluasi PR yang didasarkan pada pada tiga level kedalaman dan kesesuaian program Public Relations (Public Relations Review, Vol.16, No. 2, 1990: 3-24). Dalam evaluasi dibagi menjadi tiga bagian. Bagian pertama yaitu level output adalah evaluasi mengenai pencapaian target audience atau sasaran program serta media placement yang terjadi baik sebelum terlaksananya program, saat terlaksana, maupun pasca terlaksananya program.

Bagian kedua yaitu level intermediate menjelaskan mengenai bagaimana mengukur pemahaman, retensi, kesadaran, dan penerimaan target audiens dengan program yang diterima. Lalu apakah mereka 
Jurnal SOSIO DIALEKTIKA 6 (2) (2021)

p-ISSN: 2540.8941 e-ISSN: 2623.2944

e-mail; sosiodialektika@unwahas.ac.id

doi; http://dx.doi.org/10.31942/sd.v6i2.5677
Evaluasi Komunikasi: Studi Kasus

Pelaksanaan Program

Pemberdayaan Masyarakat

Penggiat Anti Narkoba Oleh BNN

Jakarta Timur

terus mengingat dan memahami mengapa program ini diberlakukan, apa makna dan tujuan dari pelaksanaan program sehingga target audiens dapat melaksanakan program ini karena adanya kesadaran untuk meningkatkan diri mereka sendiri menjadi lebih baik.

Bagian ketiga adalah advanced level, di mana pada level ini sudah tercermin tujuan jangka panjang dari hasil audit dan implementasi program. Dalam level ini diharapkan sudah tumbuh rasa terbiasa dari target audiens untuk melaksanakan program ini dengan baik dan tanpa paksaan atau menjadi kebiasaan sehari-hari yang merubah behavior dan attitude mereka. Lalu mereka juga sudah bisa memberikan opini mereka baik terhadap perubahan yang ada, sampai masukan kepada perusahaan seperti pujian kepuasan, dan menjadi representative perusahaan yang baik dihadapan seluruh publik. Analisis yang dilakukan pada tahapan ini akan didasarkan pada levellevel yang telah di jelaskan di atas.

\section{Gambar.1}

\section{Evaluasi Model Yardstick Terhadap Program BNN di Jakarta}

\section{Timur}

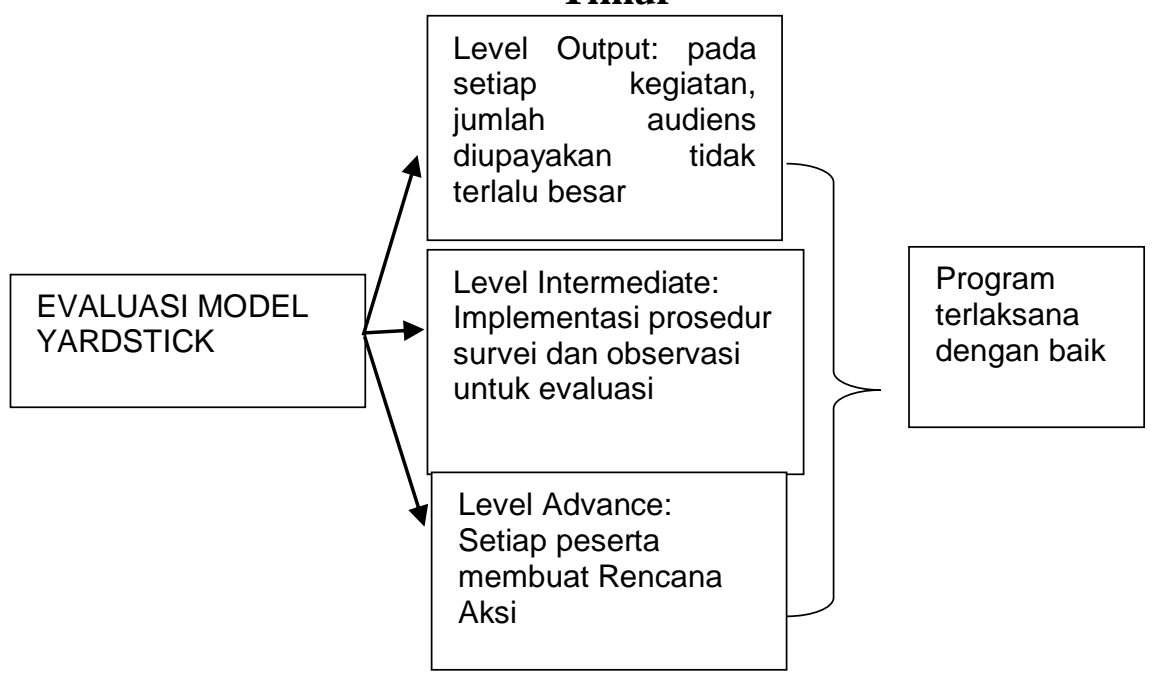

Level Output (Level 1, yaitu evaluasi output seperti pengaruh dari pemilihan media dengan melihat jumlah total audiens yang dapat dijangkau. Artinya apakah penempatan pesan pada media tertentu sudah cukup menjangkau target audiens). Dalam kaitan ini, program pemberdayaan masyarakat penggiat anti-narkoba di Jakarta Timur 
Jurnal SOSIO DIALEKTIKA 6 (2) (2021)

p-ISSN: 2540.8941 e-ISSN: 2623.2944

e-mail; sosiodialektika@unwahas.ac.id

doi; http://dx.doi.org/10.31942/sd.v6i2.5677
Evaluasi Komunikasi: Studi Kasus

Pelaksanaan Program

Pemberdayaan Masyarakat

Penggiat Anti Narkoba Oleh BNN

Jakarta Timur

telah memastikan pada setiap kegiatan, diupayakan jumlah audiens nya tidak terlalu besar, sekitar 20 - 30 peserta. Hal ini dimaksudkan agar efektifitas penyerapan pesan dapat di lakukan dengan baik. Sedangkan pada level Medium yang digunakan untuk menyampaikan pesan utama nya adalah melalui Narasumber. Oleh karena itu, di dalam berbagai kegiatan yang dilaksanakan oleh BNN di wilayah Jakarta Timur telah memperhatikan pemilihan narasumber yang berkompeten sangat penting untuk dilakukan, kemudian ditunjang dengan brochure dan buku panduan sebagai pengingat informasi yang sudah disampaikan.

Kemudian, pada level Intermediate (Level 2 yaitu evaluasi lanjutan dan memperhitungkan pemahaman kesadaran \& penerimaan). Ketika pesan sudah ditempatkan pada media tertentu, perlu dievaluasi apakah pesan yang sampai pada audiens sesuai dengan pesan yang diharapkan sampai pada audiens.) Berdasarkan wawancara dengan narasumber di dapatkan keterangan bahwa pada saat sebelum tiap sesi berakhir pihak BNN telah memiliki prosedur kuisoner memberikan evaluasi mengenai para Narasumber. Evaluasi itu berupa bagaimana pemberian materinya dari prespective para pesertanya. Seperti yang dijelaskan dalam hasil wawancara berikut,

Berdasarkan hasil survey yang dilakukan selesai training, kita dapat mengukur bagaimana penyerapan pesan yang sudah disampaikan. Survey yang di sebar juga menjadi patokan untuk menentukan apakah narasumber tersebut bisa di gunakan kembali untuk kegiatan selanjutnya (Siagian, Wawancara Pribadi, 2021).

Dengan demikian, survey merupakan patokan utama apakah peserta dapat menerima pesan dengan baik. Berdasarkan data yang didapat dari survei yang dilakukan, BNN melakukan analisis untuk mengukur ketercapaian dari tujuan kegiatan. Selain survei, pihak BNN 
Jurnal SOSIO DIALEKTIKA 6 (2) (2021)

p-ISSN: 2540.8941 e-ISSN: 2623.2944

e-mail; sosiodialektika@unwahas.ac.id

doi; http://dx.doi.org/10.31942/sd.v6i2.5677
Evaluasi Komunikasi: Studi Kasus

Pelaksanaan Program

Pemberdayaan Masyarakat

Penggiat Anti Narkoba Oleh BNN

Jakarta Timur

juga menerapkan analisis melalui observasi terhadap reaksi dan antusiasme peserta kegiatan yang dilaksanakan.

Terakhir, pada Level Advance (Level 3 merupakan level advance, fokus pada pengukuran perubahan opini, perubahan sikap sampai pada perubahan tingkah laku). Berlandaskan pada kegiatan yang dilaksanakan dapat dipahami bahwa target utama dari kegiatan ini adalah para pendidik yang nantinya akan dibina menjadi penggiat anti narkoba, oleh karena itu ukuran keberhasilan nya dapat dilihat dari apakah para peserta tersebut melakukan perubahan perilaku setelah menerima pesan utama dari bimbingan teknis tersebut. Salah satu indicator keberhasilannya adalah dilihat dari kegiatan yang dilakukan setelah peserta penggiat Anti Narkoba mendapatkan pelatihan. Seperti yang sudah dijelaskan sebelumnya, pada saat setelah kegiatan, BNN memberikan lembar rencana aksi para penggiat tersebut, artinya dari rencana tersebut, dengan sendirinya BNN dapat melihat bagaimana perubahan perilaku nya. Lebih lanjut BNN juga akan kembali menfollow up dengan mendatangi kembali para peserta untuk menanyakan realisasi dari rencanya yang sudah dibuat, apakah hal tersebut sudah benar terlaksana atau tidak, dan apabila sudah, apakah ada kendala yang berarti atau tidak. Pada dasarnya para peserta bimbingan teknis ini adalah para pendidik di institusinya masing masing, artinya pengetahuan dasar mengenai bahaya narkoba sudah mereka pahami, akan tetapi seberapa jauh pemahaman tersebut itulah yang menjadi pertanyaan utama. Untuk mendapatkan jawaban tersebut, biasanya dapat dipantau dari reaksi para peserta didik pada saat diberikannya bimbingan teknis, antusiasme para peserta menjadi faktor evaluasi apakah mereka mendapatkan pengetahuan baru yang bisa menjadi patokan dalam menjalankan peran mereka sebagai penggiat anti Narkoba di lingkungan pendidikan.

Untuk memastikan hal ini tercapai, para peserta bimbingan harus mengisi lembar rencana aksi yang akan dilakukan dilingkungan 
Jurnal SOSIO DIALEKTIKA 6 (2) (2021)

p-ISSN: 2540.8941 e-ISSN: 2623.2944

e-mail; sosiodialektika@unwahas.ac.id

doi; http://dx.doi.org/10.31942/sd.v6i2.5677
Evaluasi Komunikasi: Studi Kasus

Pelaksanaan Program

Pemberdayaan Masyarakat

Penggiat Anti Narkoba Oleh BNN

Jakarta Timur

pendidikannya masing masing, artinya dari rencana tersebut dapat diukur seberapa jauh perubahan yang dilakukan. Di dalam lembar rencana aksi yang diterima, ada peserta bimbingan yang mengisi rencana aksinya cukup banyak, artinya peserta mengalami perubahan setalah dilakukannya bimbingan teknis, namun ada juga yang tidak mengisi sama sekali, artinya bimbingan teknis yang diberikan kurang berhasil.

Sedangkan kendala-kendala yang ditemukan ketika melaksanakan program-program ini juga terjadi. Dalam setiap proses kegiatan, selalu ada kendala yang terjadi, demikian juga akan ada keberhasilan juga yang didapat, artinya kendala itu merupakan bagian dari proses, pertanyaannya apakah usaha yang dilakukan bisa mengatasi kendala kendala tersebut sehingga tujuan pelaksanaan kegiatan dapat tetap di jalankan. Hal yang bisa dilakukan adalah melihat apakah kendala tersebut bisa diatasi dengan sumberdaya yang ada, contohnya apabila peserta tidak memahami materi, diupayakan setelah kegiatan bimbingan ada proses tanya jawab, sehingga dapat melihat sejauh mana pemahaman materinya. Demikian juga dengan kendala yang bersifat teknis, sebisa mungkin diupayakan solusi yang terbaik. Ada beberapa faktor yang sering kali terjadi, antara lain faktor teknis, contohnya Narasumber yang terlalu monoton dalam memberikan materi, banyaknya interupsi pertanyaan, pada saat bimbingan masih disibukan dengan tugas tugas keseharian para peserta, dan lain sebagainya.

Berlandaskan evaluasi di atas dapat disimpulkan bahwa sejauh ini seluruh kegiatan sudah berhasil dilaksanakan dengan baik, dan masih berkelanjutan hingga hari ini. BNN terus melakukan berbagai pelatihan, bimtek dan evaluasi untuk setiap kegiatan tersebut. Beberapa parameter yang dapat dijadikan acuan dari keberhasilan BNN adalah capaian BNN selama 7 tahun berhasil menyandang predikat "Wajar Tanpa Pengecualian" dari Badan Pemeriksa 
Jurnal SOSIO DIALEKTIKA 6 (2) (2021)

p-ISSN: 2540.8941 e-ISSN: 2623.2944

e-mail; sosiodialektika@unwahas.ac.id

doi; http://dx.doi.org/10.31942/sd.v6i2.5677
Evaluasi Komunikasi: Studi Kasus

Pelaksanaan Program

Pemberdayaan Masyarakat

Penggiat Anti Narkoba Oleh BNN

Jakarta Timur

Keuangan (BPK) sebagai bentuk apresiasi atas penyelenggaraan pengelolaan keuangan negara yang transparan dan akuntabel. Sementara untuk fungsi utama BNN sebagai institusi yang melakukan tindak pencegahan dan pemberantasan penyalah gunaan dan peredaran gelap narkotika dan bahan adiktif lainnya, angka Prevalensi terhadap narkotika mulai tahun 2011 sampai dengan tahun 2019 terjadi penurunan yang cukup signifikan. Disamping itu, menurut Data Angka Prevalensi Nasional tahun 2019 terhadap orang yang pernah memakai narkotika menjadi berhenti menggunakan dan tidak mengkonsumsi narkotika kembali, terjadi penurunan sekitar 0,6\% dari jumlah 4,53 juta jiwa $(2,40 \%)$ menjadi 3,41 juta jiwa $(1,80 \%)$, sehingga hampir sekitar satu juta jiwa penduduk Indonesia berhasil diselamatkan dari pengaruh narkotika.

Indonesia terpilih oleh UNODC sebagai negara yang memiliki metode, modul dan juga praktek-praktek yang bisa diajarkan di negara-negara lain seperti dijelaskan oleh narasumber sebagai berikut:

Kita ada tuh. Kalau nanti mau mendalami, kita ada Mba Eva di BNN yang bersama dengan Prof Pulina dulu mengembangkan standar pencegahan internasional. Nah Indonesia sudah menjadi role model trus dia mengajarkan ke Afrika Selatan. Termasuk di sini kami memiliki staf Ibu Wina, yang juga memiliki terobosan untuk mengadakan rehab di dalam ruang, dimana tahun lalu kita memenangkan salah satu model dengan mencontohkan salah satu pengguna narkoba yaitu orang-orangan dalam masyarakat Betawi yang terpaksa menggunakan karena dipaksa oleh lingkungannya saat harus menjadi ondelondel tapi tidak memiliki kekuatan dan biaya. Ini menarik buat UNODC sehingga diketahui bahwa di Indonesia ditemukan narkoba itu banyak digunakan untuk mendukung penghasilan agar dapat bertahan di situasi yang sulit di kemiskinan kota.. (Widagdo, Wawancara Pribadi, 2021). 
Jurnal SOSIO DIALEKTIKA 6 (2) (2021)

p-ISSN: 2540.8941 e-ISSN: 2623.2944

e-mail; sosiodialektika@unwahas.ac.id

doi; http://dx.doi.org/10.31942/sd.v6i2.5677
Evaluasi Komunikasi: Studi Kasus

Pelaksanaan Program

Pemberdayaan Masyarakat

Penggiat Anti Narkoba Oleh BNN

Jakarta Timur

\section{SIMPULAN}

Berlandaskan analisis yang telah dilakukan di atas dapat ditarik suatu kesimpulan bahwa pada program-program yang dilaksanakan oleh BNN di Jakarta Timur telah sesuai dengan prinsip-prinsip public relations. Programprogram yang dilaksanakan telah didasarkan pada analisis situasi yang memberikan satu pemahaman strategis bahwa terdapat ancaman penyalahgunaan narkoba di masyarakat bahkan secara data yang tersedia mengancam generasi muda Indonesia. Oleh karenanya dilakukan perancangan program dan strategi aksi untuk mengantisipasi meningkatnya penyalahgunaan narkoba di masyarakat Jakarta Timur. Program tersebut fokus pada para pendidik yang nantinya akan menjadi relawan penggiat anti narkoba. Kemudian ketika program tersebut dievaluasi menggunakan model Yardstick, didapatkan satu hasil evaluasi bahwa berlandaskan pada analisis level output, intermediate, dan advance didapatkan satu pemahaman bahwa program tersebut terlaksana dengan baik. Meskipun terdapat beberapa kendala seperti Narasumber yang terlalu monoton dalam memberikan materi, banyaknya interupsi pertanyaan, pada saat bimbingan masih disibukkan dengan tugas tugas keseharian para peserta, dan lain sebagainya. Namun, program-program pemberdayaan masyarakat oleh BNN untuk mengantisipasi penyalahgunaan narkoba harus terus diperkuat dan dikembangkan demi menjaga masa depan bangsa Indonesia. 
Jurnal SOSIO DIALEKTIKA 6 (2) (2021)

p-ISSN: 2540.8941 e-ISSN: 2623.2944

e-mail; sosiodialektika@unwahas.ac.id

doi; http://dx.doi.org/10.31942/sd.v6i2.5677
Evaluasi Komunikasi: Studi Kasus

Pelaksanaan Program

Pemberdayaan Masyarakat Penggiat Anti Narkoba Oleh BNN

Jakarta Timur

\section{DAFTAR PUSTAKA}

Cutlip, S., Center, S., \& Broom, G, Effective Public Relations, Jakarta: Prenada Media, 2011.

Elvinaro, Aldianto \& Soemirat, Soleh, Dasar-Dasar Public Relation, Bandung: PT. Remaja Rosdakarya, 2003.

Effendy, O. U., Hubungan Masyarakat: Suatu Studi Komunikologis, Bandung: PT Remaja Rosdakarya, 2006.

Gregory, A. (Ed.), Public Relations in Practice, UK: Kogan Page Publishers, 2004.

Nopitasari, D., \& Rostyaningsih, D., Implementasi ProgramPemberdayaan AlternatifMasyarakat Perkotaan Pada Kawasan Rentan Narkoba di Kampung Pertanian Jakarta Timur. Journal Of Public Policy And Management Review, 6(2)., 2017.

http://marefateadyan.nashriyat.ir/node/150

Naskah Cetak Biru Pemberdayaan Masyarakat. (n.d.). retrieved July 7, 2020 from https://bnn.go.id/konten/unggahan/2019/10/blue-print-dayamasBNN.pdf

Nawawi \& Martini, Metode Penelitian Bidang Sosial, Yogyakarta, Gajah Mada University Press, 2003.

Ruslan, Rosady, Kiat dan Strategi Kampanye Public Relation, Jakarta: Penerbit PT. Raja Grafindo Persada, 2005.

Sulistyaningtyas, I. D. 2010. Riset sebagai Ujung Tombak Keberhasilan Program Public Relations.Jurnal Ilmu Komunikasi, 7(2). DOI: https://doi.org/10.24002/jik.v7i2.190

Walter K. Lindenmann, Walter K. Research, Evaluation and Measurement: A National Perspective' in "Public Relations Review", 16 (2): 3-24, 1990.

Widagdo, H.P., Wawancara Pribadi, Jakarta, 2021.

Siagian, A., Wawancara Pribadi, Jakarta, 2021.

Waripintoko, W., Wawancara Pribadi, Jakarta, 2021.

Prakoso, O.S., Wawancara Pribadi, Jakarta, 2021. 